\title{
Population Administration Services Through the Population Administration System Application Program (Study of Population Service Processes through the Population Administration System Application Program in Batu City)
}

\author{
Didik Supriyanto \\ Doctoral Candidate In Social Sciences Postgraduate Program \\ at Merdeka University Malang \\ Samsul Wahidin \\ Professor Of Social Science Doctoral Program \\ At the Postgraduate Program Merdeka University \\ Kridawati Sadhana \\ Prospective professor of Social Science Doctoral Program at \\ the Postgraduate Program at Merdeka University Malang
}

\begin{abstract}
Online Population Administration Process services in Batu City reflect the attitude that truly serving the community will be manifested through the quality of service provided to the community. The government as a service provider for the community is required to provide increasingly quality services. Moreover, in the face of competition in the era of globalization, the quality and service of government officials will be increasingly challenged to be more optimal and able to respond to the increasingly high demands of the community, both in terms of quality and in terms of community satisfaction with the services they get. The method used in this research is to use qualitative methods. The results of this study indicate that: (1) The Population Administration Service Process through the SIAP Application Program in Batu City greatly helps the population administration service process to be more efficient and effective. This application makes it easy for all administrative processes that have seemed complicated and long; (2) Coordination with Related Fields Regarding Population Administration through the SIAP Application Program in Batu City, channeled to officials implementing the program by means of the head of the public service provider or the appointed official responsible for providing services and resolving complaints / problems in the implementation of public services; (3) Factors that hamper the Batu City Government in Carrying out Population Administration Services through the SIAP Application Program in Batu City are the gap in service quality which is not only caused by inadequate facilities and infrastructure, limited human resources and also management of public service systems. not yet integrated; (4) Factors Supporting the Government of Batu City in Providing Population Administration Services through the SIAP Application Program in Batu City, namely the attitude and commitment of the implementers in providing population administration services through the SIAP application program in Batu City. The analysis and discussion of this research are: (1) The Process of Population Administration Services through the SIAP Application Program in Batu City, the SIAP application program in Batu City is a means of the process of population administration services for the people of Batu City. The SIAP application really helps the population administration service process to be more efficient and effective. This application makes it easy for all administrative processes that have seemed complicated and long. Regarding online services carried out in Batu City through several websites that are separated based on their needs. Among other things, https://bit.ly/dafdukbatu is used to serve family cards (KK), changing electronic identity cards (KTP), Child Identity Cards (KIA), moving letters and residence certificates (SKTT), management birth certificates, death and marriage certificates and https://bit.ly/capil-batu to provide services for administering divorce and changing citizenship. The services are provided for 6 hours starting from 08.00-14.00 WIB. Likewise, the information technology in Batu City is very sophisticated. This is evidenced by the variety of applications and webs that provide information about Batu City to applications that can help government administration in Batu City; (2) Coordination with Related Fields Regarding Population Administration through the SIAP Application Program in Batu City. Population administration services through the SIAP application program in Batu City are channeled to officials who will carry out the program by means of leaders of public service providers or appointed officials responsible for providing services and resolving complaints / problems in the implementation of public services that the Head of public service providers or officials who appointed to be responsible for providing services and resolving complaints / problems in the implementation of public services. Complexity in making population administration service programs through the SIAP application program in Batu City, especially what occurs between the executive and the legislature, namely the Legislature in charge of making laws. The executive in charge of
\end{abstract}


implementing or enforcing laws; (3) Factors that hinder the Batu City Government in Carrying out Population Administration Services through the SIAP Application Program in Batu City, the readiness of human resources in the Batu City Government in carrying out population administration services through the SIAP application program in Batu City, there is a gap in the quality of these services apart from being inadequate facilities and infrastructure, limited human resources and inadequate management of public service systems. The gap in the quality of services is not only caused by inadequate facilities and infrastructure, limited human resources and also management of public service systems that are not yet integrated; (4) Factors Supporting the Batu City Government in Providing Population Administration Services through the SIAP Application Program in Batu City, the attitude and commitment of the implementers in providing population administration services through the SIAP application program in Batu City, that they are certainly very fully committed to using the SIAP application this wisely so that it can lead to many good benefits for the people of Batu City in particular. From the results of this study the researcher recommends that 1. Population Administration Service Process through the SIAP Application Program in Batu City to make it easier for all administrative processes that have seemed complicated and long, should be further improved. 2. Coordination with Related Fields Regarding Population Administration through the SIAP Application Program in Batu City, channeled to officials who will implement public service programs or officials appointed to be responsible for service delivery and resolution of complaints / problems in the implementation of public services that the Head of public service providers or officials those appointed to be responsible for providing services and resolving complaints / problems in the implementation of public services, guidance should always be carried out; 3. Factors Obstructing Batu City Government in Providing Population Administration Services through the SIAP Application Program in Batu City, namely the readiness of human resources in carrying out population administration services through the SIAP application program, will be minimized. 4. Factors Supporting the Government of Batu City in Performing Population Administration Services through the SIAP Application Program, namely the attitude and commitment of the implementers in carrying out population administration services must always be maintained.

Keywords: Services, Population Administration, Information Systems, Rural Applications

DOI: $10.7176 /$ RHSS/11-10-05

Publication date:May $31^{\text {st }} 2021$

\section{INTRODUCTION}

The population of Batu City, East Java Province from time to time continues to increase. This population growth certainly brings consequences, including the provision of adequate public facilities and job opportunities that ensure the survival and welfare of the community. As per BPS data, the population of Batu in 2013 was 196,179 people and in 2014 it was 198,608 people or a population growth rate of $1.23 \%$ per year. In 2015 the population of Batu City became 200,485 people or a population growth rate of $0.95 \%$ per year. In 2016 the population of Batu City became 202,319 people or the population growth rate was $0.91 \%$ per year. In 2017 the population of Batu City became 203,997 people or the population growth rate was $0.83 \%$ per year. The population growth rate in Kota Batu is higher than that in East Java, which is $0.53 \%$.

The large and quality population in Batu City is the basic capital and the potential for increased development in all fields. In Batu City in 2017, the largest population was in Batu District, namely 94,966 people (46.55\%). However, the highest population growth rate was found in Junrejo District at $1.07 \%$. The population growth rate in Bumiaji District $(0.525 \%)$ is the lowest of the 2 Districts.

In Kota Batu, people aged 15-64 years are considered productive, while residents aged 0-14 years and over 65 years are considered unproductive. The percentage of productive age reached $69.13 \%$. Meanwhile, the population aged $0-14$ years and over 65 years had the respective percentages of $23.99 \%$ and $6.89 \%$.

The population density in Batu City is quite dense, reaching 1,024 people per square kilometer. Where the highest population density is in Batu District with 2,089 people per km2, five times bigger than Bumiaji District. The population is always dynamic because in their life they will experience vital events such as birth, displacement, marriage, illness and also experiencing death. Population data is one of the indispensable information for development planning. The development of the number, composition and distribution of the population will have a wide impact in various fields such as food, health, education, security and so on.

The HDI of Batu City has increased every year. In 2015 the HDI for Batu City was 72.62, in 2016 it was 73.53, in 2017 it was 74.26 and in 2018 it was 75.04. The HDI of Batu City is still higher than the HDI of East Java Province for the same year. The HDI of Batu City in 2017 is the 10th best ranking in all districts / cities in East Java Province, this ranking has actually remained for the last 4 years. In 2017, Surabaya was in the 1st rank in East Java Province. The first determining component of the Batu City Human Development Index is Life Expectancy $(\mathrm{AHH})$. Life expectancy $(\mathrm{AHH})$ is the average length of life that the population will achieve. Based on the calculation results, the life expectancy at birth (eo) of Batu City in 2018 is 72.37 years.

That public service itself has been regulated in Law Number 25 of 2009 concerning public services is an activity or series of activities in the context of fulfilling service needs in accordance with statutory regulations 
for every citizen and resident for goods, services, and administrative services provided by public service providers. Public service providers, hereinafter referred to as administrators, are state administering institutions, corporations, independent institutions established by law for public service activities, and other legal entities established solely for public service activities. The implementation of autonomy based on law number 23 of 2014 concerning Regional Government article 2 as referred to in paragraph (2) carries out the widest possible autonomy, except for the affairs of the central government. The purpose of providing the widest possible autonomy is to improve public welfare, public services and regional competitiveness. By improving the welfare of the community, it is hoped that it can accelerate its realization by improving its services in the regions and empowering the community or by community participation in the implementation of regional development.

Online Population Administration Process services in Batu City reflect the attitude that truly serving the community will be realized through the quality of services provided to the community. The government as a service provider for the community is required to provide increasingly quality services. Moreover, in the face of competition in the era of globalization, the quality and service of government officials will be increasingly challenged to be more optimal and able to respond to the increasingly high demands of the community, both in terms of quality and in terms of community satisfaction with the services they get.

With the conditions as described, it is imperative for us to study further in the hope that alternative solutions or solutions to solving problems of some of the obstacles related to the online Population Administration Service Process in Batu City are interested in writing about "Administrative Services. Population through the Rural Application Information System Program (Study of Population Service Processes through the Rural Application Information System Program in Batu City).

\section{RESEARCH RESULT}

A. The Process of Population Administration Services through the SIAP Application

\section{Program in Batu City}

The SIAP application program in Batu City is a means in the process of population administration services for people in Batu City. The SIAP application really helps the population administration service process to be more efficient and effective. This application makes it easy for all administrative processes that have seemed complicated and long. Regarding online services carried out in Batu City through several web sites that are separated based on their needs. Among other things, https://bit.ly/dafduk-batu is used to serve family cards (KK), change electronic identity cards (KTP), Child Identity Cards (KIA), moving letters and residence certificates (SKTT), management birth certificates, death and marriage certificates and https://bit.ly/capil-batu to provide services for administering divorce and changing citizenship. The services are provided for 6 hours starting from 08.00-14.00 WIB. Likewise, the information technology in Batu City is very sophisticated. This is evidenced by the variety of applications and webs that provide information about Batu City to applications that can help government administration in Batu City.

The role of human resources in the population administration service process through the SIAP application program in Batu City is the activator / user of the application, because without HR, this application cannot run properly. With this application, it will be very beneficial for its users because the sophistication of technology can make their performance easier.

The use of information technology is inseparable from the role of computers and communication technology in the process of population administration services through the SIAP application program in Batu City. The SIAP application certainly cannot be separated from computer equipment and communication technology, because the application must be installed and used on a computer. With this application is also an illustration of technological developments, especially in the field of information and communication.

Services in the form of managing the population administration service process through the SIAP application program in Batu City are carried out, among others: The first step is to set up network protocol settings. After that the next step is to install an online communication support application. An example of an application that is easy to use compared to other chat applications, free of charge, and guaranteed security is Google Hangout.

The population administration service process through the SIAP application program in Batu City is related to the Determination of Service Standards, which means that the determination of service standards is carried out through the process of identifying types of services, identifying customers, identifying customer expectations, formulating service vision and mission, analyzing processes and procedures, facilities and infrastructure, service time and cost.

The population administration service process through the SIAP application program in Batu City is related to the Development of Standard Operating Procedures (SOP), that to ensure that the service process can run consistently, Standard Operating Procedures are required. With the SOP, the processing is carried out internally in the service unit can run according to clear references, so that it can run consistently.

The process of population administration services through the SIAP application program in Batu City is 
related to the Development of a Customer Satisfaction Survey that: To maintain community satisfaction, it is necessary to develop a mechanism for assessing community satisfaction with services provided by public service providers. In the concept of service management, customer satisfaction can be achieved if the service products provided by service providers meet the quality expected by the community. Therefore, customer satisfaction surveys have an important meaning in efforts to improve public services.

The population administration service process through the SIAP application program in Batu City is reviewed by Transparency. Service standards must be easily accessible to the public, that: In the implementation of public services, the government as the provider of public services must provide access for citizens to know everything related to the public services that are carried out, such as: requirements, procedures, costs, and the like.

The population administration service process through the SIAP application program in Batu City is viewed from Progressive (progressive). Whatever work we are engaged in, if we have passion and a progressive mindset, will make work more attractive, namely: In providing wholehearted service, we need to constantly try to create new, more effective, more efficient, and more attractive ways to improve. the quality of our service. We will never feel satisfied with the results we get, for that we will always try to find creative ways to offer better ones.

The process of population administration service through the SIAP application program in Batu City is viewed from Positive. Being positive is very interesting, should be warm in welcoming consumers and there are no questions or requests that are not appropriate, that being positive encourages us not to be easily discouraged by the problems we face. Being positive leads us to focus more on solving rather than on problems. Being positive is very attractive, because this attitude can change the atmosphere and spread excitement to almost all interactions with consumers.

The process of population administration service through the SIAP application program in Batu City, viewed from how to see yourself. Self-esteem is not measured by what a person has and what a person does. Have a sense of self-confidence and have the ability to relate to other people, that: if from within you see yourself yourself as a person who is positive, popular, productive, and successful, that is the behavior that you will show outside. And the way you behave outside yourself, will greatly determine the results you get.

The process of population administration service through the SIAP application program in Batu City is viewed from how others perceive it. This can be seen from the way of serving and treating consumers in a friendly and professional manner as well as being able to establish an emotional relationship with each consumer, that researchers found that someone who has a tendency to describe other people with positive words indicates that he has positive traits.

\section{B. Population Administration Service Process Application}

The process of population administration service through the SIAP application program in Batu City is viewed from how jobs are viewed. Feeling at work by paying attention to consumers and a special way of dealing with them as an individual. Regarding work as a part of itself, namely: Work is not solely for earning income. if you still think like this, you should change the Mindset right now, because it will only waste time in vain. Motivation to work should be based on a love of work itself. You also need to remember that as God's creatures, we also work to worship. The results obtained are a bonus for us for the hard work we do.

The population administration service process through the SIAP application program in Batu City, viewed from Tangibles (touchable), physical facilities, equipment, personnel and communication, that Tangibles is the company's ability to provide the best service for customers and this is a concrete thing. This means that the quality can be seen and felt directly by the customer.

The process of population administration service through the SIAP application program in Batu City, in terms of Reliability (reliable), the ability of the service unit to create the promised service appropriately, namely Reability is the company's ability to provide services to customers. If tangibles are about concrete things, reliability is arguably more abstract.

The process of population administration services through the SIAP application program in Batu City, in terms of Responsiveness, willingness to help consumers, being responsible for the quality of service provided, that responsiveness is about how companies provide services that are responsive to all customer wants and needs. Usually this responsiveness is also followed by a coherent delivery but still easy to understand.

The process of population administration service through the SIAP application program in Batu City, in terms of competence, demands to have good knowledge and skills by officials in service members, that competence is the ability or capacity of a person to do various tasks in a job, where this ability is determined by two factors which are intellectual ability and physical ability.

The population administration service process through the SIAP application program in Batu City, in terms of Courtesy, friendly, friendly attitude / behavior, responsive to consumer desires, willing to make personal contacts / relationships, that: Knowledge and politeness of employees and their ability to foster trust and confidence in users. 
The process of population administration services through the SIAP application program in Batu City, in terms of credibility (honesty), an honest attitude in every effort to attract public trust, namely honest and frank service, meaning that if there are obstacles due to an inevitable problem, it should be notified., so that people do not wait for something that is not clear.

The process of population administration services through the SIAP application program in Batu City, in terms of security (safe), the services provided must be guaranteed to be free from various dangers and risks, that the processes and products of public services or appointed officials are responsible for organizing and resolving complaints.

The process of population administration services through the SIAP application program in Batu City, in terms of Access (convenience), to make contacts and approaches, that places and locations and adequate service facilities, easily accessible to the community, can take advantage of communication and information technology.

The process of population administration services through the SIAP application program in Batu City, in terms of communications, the willingness of service providers to listen to the voices, desires or aspirations of customers, as well as the willingness to always convey new information to the public with clarity of service procedures. Service procedures must be designed as simple as possible and communicated to the service user community, that the clarity of service procedures. Service procedures must be designed as simple as possible and communicated to the service user community. personnel and communication, that Tangibles is the company's ability to provide the best service for customers and this is a concrete thing. This means that the quality can be seen and felt directly by the customer.

The process of population administration service through the SIAP application program in Batu City, in terms of Reliability (reliable), the ability of the service unit to create the promised service appropriately, namely Reability is the company's ability to provide services to customers. If tangibles are about concrete things, reliability is arguably more abstract.

The process of population administration services through the SIAP application program in Batu City, in terms of Responsiveness, willingness to help consumers, being responsible for the quality of service provided, that responsiveness is about how companies provide services that are responsive to all customer wants and needs. Usually this responsiveness is also followed by a coherent delivery but still easy to understand.

The process of population administration service through the SIAP application program in Batu City, in terms of competence, demands to have good knowledge and skills by officials in service members, that competence is the ability or capacity of a person to do various tasks in a job, where this ability is determined by two factors which are intellectual ability and physical ability.

The population administration service process through the SIAP application program in Batu City, in terms of Courtesy, friendly, friendly attitude / behavior, responsive to consumer desires, willing to make personal contacts / relationships, that: Knowledge and politeness of employees and their ability to foster trust and confidence in users.

The process of population administration services through the SIAP application program in Batu City, in terms of credibility (honesty), an honest attitude in every effort to attract public trust, namely honest and frank service, meaning that if there are obstacles due to an inevitable problem, it should be notified., so that people do not wait for something that is not clear.

The process of population administration services through the SIAP application program in Batu City, in terms of security (safe), the services provided must be guaranteed to be free from various dangers and risks, that the processes and products of public services or appointed officials are responsible for organizing and resolving complaints.

The process of population administration services through the SIAP application program in Batu City, in terms of Access (convenience), to make contacts and approaches, that places and locations and adequate service facilities, easily accessible to the community, can take advantage of communication and information technology.

The process of population administration services through the SIAP application program in Batu City, in terms of communications, the willingness of service providers to listen to the voices, desires or aspirations of customers, as well as the willingness to always convey new information to the public with clarity of service procedures. Service procedures must be designed as simple as possible and communicated to the service user community, that the clarity of service procedures. Service procedures must be designed as simple as possible and communicated to the service user community.

\section{Sociological Aspects in the Perspective of Understanding the Customer}

The population administration service process through the SIAP application program in Batu City, which is reviewed from Understanding the Customer, makes an effort to find out customer needs that in the context of transparency of licensing services including Building Permit services (IMB) is carried out through SOP (operational standards). procedure) which contains a licensing mechanism or flow so that the procedure for obtaining a permit is clearer, more open and understandable to the public that: In the context of transparency of 
licensing services including Building Permit (IMB) services, it is carried out through an SOP (standard operating procedure) which contains a mechanism or flow permits so that the procedures for obtaining permits are clearer, more open and understandable to the public.

The factors that support the Batu City Government in providing Population Administration services through the SIAP Application Program, show that the attitude and commitment of the implementers in carrying out population administration services through the SIAP application program in Batu City. This is based on the statement of Mr. Purnomo, Executive at the Batu City Education Office, who stated that: "They are certainly very committed to using the SIAP application wisely so that it can generate many good benefits for Batu City residents in particular.

The work mechanism established to manage the implementation of population administration services through the SIAP application program in Batu City, namely: the preparation stage which is the first stage in the form of activities before starting to collect data / obtain data, with preparation, the data obtained will be easier, smoother and faster.

Standard Operating Procedure (SOP) which regulates the flow of work among the implementers, in carrying out population administration services through the SIAP application program in Batu City, that the service process can run consistently requires Standard Operating Procedures. With the existence of an SOP, the processing carried out internally in the service unit can run according to clear references, so that it can run consistently.

\section{PROPOSITION}

\section{a. Proposition One}

The process of population administration services through the SIAP application program in Batu City, in terms of the behavior of officials involved in community service, is thus to ensure whether each official has carried out their functions, that: Public officials ethics are ethics that are in line with the vision and mission of Indonesia future. Starting from how to be honest, fair, and most importantly not hypocritical.

The process of population administration service through the SIAP application program in Batu City is viewed from Passionate (passion). This generates great enthusiasm for work, for yourself, and for others. Enthusiasm and attention brought to wholehearted service will distinguish how to view ourselves and work from the behavior and ways of providing service to consumers, that if we have a high passion for life, we will tend to provide service with a smile, vitality, and enthusiasm. which will infect the people we serve, so that they will feel happy working together, doing business and communicating with us.

The process of population administration services through the SIAP application program in Batu City, viewed from proactive (proactive). To achieve better service quality requires the right initiatives, that: The added value of wholehearted service is the underlying reason why we do things for others. This service is provided because there is concern and it will make a difference for our consumers.

The population administration service process through the SIAP application program in Batu City is viewed from Progressive (progressive). Whatever work we are engaged in, if we have passion and a progressive mindset, will make work more attractive, namely: In providing wholehearted service, we need to constantly try to create new, more effective, more efficient, and more attractive ways to improve. the quality of our service. We will never feel satisfied with the results we get, for that we will always try to find creative ways to offer better ones.

The process of population administration service through the SIAP application program in Batu City is viewed from Positive. Being positive is very interesting, should be warm in welcoming consumers and there are no questions or requests that are not appropriate, that being positive encourages us not to be easily discouraged by the problems we face. Being positive leads us to focus more on solving rather than on problems. Being positive is very attractive, because this attitude can change the atmosphere and spread excitement to almost all interactions with consumers.

The process of population administration service through the SIAP application program in Batu City, viewed from how to see yourself. Self-esteem is not measured by what a person has and what a person does. Having self-confidence in yourself and having the ability to relate to other people, that: if from within you see yourself as a positive, popular, productive, and successful person, that is the behavior that you will show on the outside. And the way you behave outside yourself, will greatly determine the results you get.

The process of population administration service through the SIAP application program in Batu City is viewed from how others perceive it. This can be seen from the way of serving and treating consumers in a friendly and professional manner as well as being able to establish an emotional relationship with each consumer, that researchers found that someone who has a tendency to describe other people with positive words indicates that he has positive traits.

The process of population administration service through the SIAP application program in Batu City, viewed from how to view work. Feeling at work by paying attention to consumers and a special way of dealing with them as an individual. Regarding work as a part of itself, namely: Work is not solely for earning income. if 
you still think like this, you should change the Mindset right now, because it will only waste time in vain. Motivation to work should be based on a love of work itself. You also need to remember that as God's creatures, we also work to worship. The results obtained are a bonus for us for the hard work we do.

The process of population administration service through the SIAP application program in Batu City, viewed from Tangibles (touchable), physical facilities, equipment, personnel and communication, that Tangibles is the company's ability to provide the best service for customers and this is a concrete thing. This means that the quality can be seen and felt directly by the customer.

The process of population administration service through the SIAP application program in Batu City, in terms of Reliability (reliable), the ability of the service unit to create the promised service appropriately, namely Reability is the company's ability to provide services to customers. If tangibles are about concrete things, reliability is arguably more abstract.

The process of population administration services through the SIAP application program in Batu City, in terms of Responsiveness, willingness to help consumers, being responsible for the quality of service provided, that responsiveness is about how companies provide services that are responsive to all customer wants and needs. Usually this responsiveness is also followed by a coherent delivery but still easy to understand.

The process of population administration service through the SIAP application program in Batu City, in terms of competence, demands to have good knowledge and skills by officials in service members, that competence is the ability or capacity of a person to do various tasks in a job, where this ability is determined by two factors which are intellectual ability and physical ability.

The population administration service process through the SIAP application program in Batu City, in terms of Courtesy, friendly, friendly attitude / behavior, responsive to consumer desires, willing to make personal contacts / relationships, that: Knowledge and politeness of employees and their ability to foster trust and confidence in users.

The process of population administration services through the SIAP application program in Batu City, in terms of credibility (honesty), an honest attitude in every effort to attract public trust, namely honest and frank service, meaning that if there are obstacles due to an inevitable problem, it should be notified. , so that people do not wait for something that is not clear.

The process of population administration services through the SIAP application program in Batu City, in terms of security (safe), the services provided must be guaranteed to be free from various dangers and risks, that the processes and products of public services or appointed officials are responsible for organizing and resolving complaints.

The process of population administration services through the SIAP application program in Batu City, in terms of Access (convenience), to make contacts and approaches, that places and locations and adequate service facilities, easily accessible to the community, can take advantage of communication and information technology.

The process of population administration services through the SIAP application program in Batu City, in terms of communications, the willingness of service providers to listen to the voices, desires or aspirations of customers, as well as the willingness to always convey new information to the public with clarity of service procedures. Service procedures must be designed as simple as possible and communicated to the service user community, that the clarity of service procedures. Service procedures must be designed as simple as possible and communicated to the service user community.

The population administration service process through the SIAP application program in Batu City, which is reviewed from Understanding the Customer, makes an effort to find out customer needs that in the context of transparency of licensing services including Building Permit services (IMB) is carried out through SOP (operational standards). procedure) which contains a licensing mechanism or flow so that the procedure for obtaining a permit is clearer, more open and understandable to the public that: In the context of transparency of licensing services including Building Permit (IMB) services, it is carried out through an SOP (standard operating procedure) which contains a mechanism or flow permits so that the procedures for obtaining permits are clearer, more open and understandable to the public.

Based on the above analysis, a minor proposition 1 can be drawn up as follows: If the Population Administration Service Process through the SIAP Application Program is carried out properly, then the Population Administration Service in Batu City will be orderly.

\section{b. Proposition Two}

Population administration services through the SIAP application program in Batu City are channeled to officials who will implement the program by means of the leadership of public service providers or appointed officials responsible for providing services and resolving complaints / problems in the implementation of public services that the Head of public service providers or officials those appointed to be responsible for providing services and resolving complaints / problems in the implementation of public services.

The complexity in making the administration service program for the population through the SIAP application program in Batu City, especially what happens between the executive and the legislature, namely the 
Legislature who is in charge of making laws. The executive in charge of implementing or enforcing laws. The complexity of creating a population administration service program through the SIAP application program in Batu City is due to opposition / opposition from the public for this policy.

Whereas Opposition in the world of politics means opposing parties in the representative council, etc. which oppose and criticize the political opinions or policies of the ruling class. The complexity in making a population administration service program through the SIAP application program in Batu City is due to the need to reach consensus between competing goals when formulating the policy. That consensus is a phrase to produce or make an agreement that is mutually agreed upon between groups or individuals after debates and research are carried out in collective intelligence to obtain consensus on decision making. Consensus carried out in abstract ideas, does not have implications for practical political consensus but follow-up implementation of the agenda will be easier to do in influencing political consensus.

The complexity in making a population administration service program through the SIAP application program in Batu City is due to the existence of this new policy in which the formulators have not really mastered the problem (about this it is often said to be an effort to avoid responsibility), that the formulation of policies is the development of effective policies and it is acceptable to address what issues have been placed on the policy agenda.

The complexity in making a population administration service program through the SIAP application program in Batu City is due to legal regulations. Namely the rule of law is the way in which citizens are governed by the rule of law and not by the power of others. Law is a legal proposition that treats everyone in the same situation equally.

The complexity of population administration services through the SIAP application program in Batu City is implemented, that just as indicators to measure the complexity of administrative services are quite varied, the way to measure the complexity index of administrative services is also quite varied. The World Bank in its Ease of Doing Business report uses the "Distance from the Frontier" approach before determining the ranking of each country in the ease of doing business in the country concerned. Difficulties that arise in population administration services through the SIAP application program in Batu City. That citizens who use public services are not satisfied with the services provided by the government bureaucracy. This happens because all regulations and service systems are determined unilaterally by the government bureaucracy without asking or trying to understand the difficulties, hopes and aspirations of citizens for the services that citizens actually want.

The population administration service program through the SIAP application program in Batu City is against other policies. That is, a statutory regulation can only be revoked and declared invalid by statutory regulations of the same or higher level. The revocation of statutory regulations with statutory regulations of a higher level is carried out if the higher statutory regulations are intended to accommodate all or part of the material of the lower legislative regulations that were revoked.

There are many influences from various interest groups on the population administration service program through the SIAP application program in Batu City. That services that meet the interests of the public are called public services, namely activities carried out by a person or group of people on the basis of material factors through certain systems, procedures and methods in order to fulfill the interests of others in accordance with their rights.

Based on the above analysis, minor proposition 2 can be drawn up as follows: If coordination with related fields regarding Population Administration through the SIAP Application Program runs smoothly, the Population Administration Service in Batu City will be orderly.

\section{c. Proposition three}

With regard to the factors that hinder the Batu city government in carrying out population administration services through the SIAP application program in Batu City, the readiness of human resources in the Batu City Government in carrying out population administration services through the SIAP application program in Batu City, there is a gap in the quality of services apart from being caused by factors inadequate facilities and infrastructure, limited human resources and inadequate management of public service systems. The discrepancy in the quality of services is not only caused by inadequate facilities and infrastructure, limited human resources and also management of public service systems that are not yet integrated.

The existence of the number of staff, who have the skills (abilities) in accordance with those needed to carry out population administration services through the SIAP application program in Batu City are very adequate, and on average all of them are technology literate so they can run the SIAP application properly.

The existence of technical guidelines for carrying out population administration services through the SIAP application program in Batu City, namely in the form of implementation instructions and technical instructions. Both of these documents are important and must be read by participants to be used as a reference and include important information about this application itself. These operational and technical guidelines are in accordance with the prevailing laws and regulations.

The data related to carrying out population administration services through the SIAP application program in 
Batu City is complete, and of course it must be updated every day so that it is always up to date, so that the SIAP application can also help the administrative process properly and effectively and efficiently. The authority to bring cases to court for the implementers, in carrying out population administration services through the SIAP application program in Batu City, of course, Batu City government officials have the authority to bring cases to court if the executors violate the law, because as state officials, of course they must uphold honesty.

The authority to provide goods and services for executors, in carrying out population administration services through the SIAP application program in Batu City, namely Batu City government officials is authorized to provide goods and services for executors, because it is the duty of a leader to meet the needs of his subordinates.

The authority to obtain and use funds for implementers, in carrying out population administration services through the SIAP application program in Batu City, states that the use of funds must be with the permission of the authorized treasurer so that misunderstandings do not occur later. The authority to acquire and use staff, for executors in carrying out population administration services through the SIAP application program in Batu City. that: Using staff, especially staff who are reliable in their fields, is certainly very permissible as long as it is still in accordance with the applicable law, namely the Job Creation Law which also regulates Manpower.

The authority to request cooperation with other government agencies is for the implementers in carrying out population administration services through the SIAP application program in Batu City. namely: Asking for cooperation, of course, must be with the permission of the local government officials, because all matters related to external cooperation must be known by the leader, to minimize the bad possibilities that occur.

The existence of an office to provide population administration services through the SIAP application program in Batu City. that: Office is not a priority matter, because this application can be done from anywhere, and through the sophistication of existing technology, we can coordinate easily through teleconferences that exist today.

The existence of a computer to provide population administration services through the SIAP application program in Batu City. that: A computer is of course very necessary to run this application, because without a computer this application cannot be run.

Population problems must be managed appropriately to support national and regional development. that: As a state apparatus, we must be mandated in carrying out our duties, namely managing existing data appropriately instead of misusing the data because it can backfire for us.

A large population, it will be meaningful if some of them are able to work and participate in development. On the other hand, a large population will add to the economic and development burden if it is not managed properly. namely: A large population will not add to the economic burden if it can be properly educated, so they can also work as creatively as possible to play a role in running the economy. In accordance with the provisions of the law on population administration, the administration of population administration is part of the affairs of the regional government. that: The Administrator is the Government, provincial government and district / city government which is responsible and authorized in Population Administration affairs.

Population information must be managed properly and correctly, so that it can be used as material for consideration in formulating development policies. that: Well managed data will produce good policies because the policies to be issued are of course formulated based on considerations from existing data.

Population administration functions are very vital, not just numbers and data. that: Law Number 23 of 2006 concerning Population Administration as amended by Law Number 24 of 2013 states that the provincial government is obliged and responsible for carrying out population administration, including the management and presentation of population data on a provincial scale carried out by the governor.

Based on the above analysis, minor proposition 3 can be drawn up as follows: If the factors that hinder the implementation of population administration services through the SIAP application program can be minimized, then Population Administration Services in Batu City will be orderly.

\section{d. Proposition Four}

That the factors that support the Batu city government in providing population administration services through the SIAP application program in Batu city, show that the attitude and commitment of the implementers in carrying out population administration services through the SIAP application program in Batu City, that they are certainly very fully committed to using the SIAP application. this wisely so that it can cause many good benefits for the people of Batu City in particular.

The understanding of the implementer in carrying out population administration services through the SIAP application program in Batu City is that the implementer is very familiar with how to operate this application because the application is very easy to understand, so it doesn't take a long time to understand it. The acceptance of the implementer in carrying out population administration services through the SIAP application program in Batu City is that the implementer has very much accepted the existence of this application because the application has many positive impacts both for the implementer and for local residents, especially Batu City residents. 
The impartiality and rejection of the implementers in carrying out population administration services through the SIAP application program in Batu City, of course there is no impartiality in the acceptance of this application. The intensity of the response or the response of the implementers in carrying out population administration services through the SIAP application program in Batu City is that almost all implementers give a positive response to the existence of the SIAP application because it can simplify their performance.

The work mechanism established to manage the implementation of population administration services through the SIAP application program in Batu City is the preparation stage which is the first stage in the form of activities before starting to collect data / obtain data, with preparation, the data obtained will be easier, smoother and faster. Next is the Implementation of Online Communication. The last stage is Follow-up Online Communication. Follow-up information includes the following: 1. Communication; 2. Storage (Storing); 3. Rediscovery; 4. Reproduction.

Standard Operating Procedure (SOP) which regulates the flow of work among the implementers, in carrying out population administration services through the SIAP application program in Batu City, that the service process can run consistently requires Standard Operating Procedures. With the existence of SOPs, the processing that is carried out internally in the service unit can run according to clear references, so that it can run consistently so that to ensure that the service process can run consistently, Standard Operating Procedures are required. Based on the above analysis, minor proposition 4 can be arranged as follows: If the supporting factors in carrying out population administration services through the SIAP application program can be maximized, then Population Administration Services in Batu City will be orderly.

\section{e. Major's Proposition}

Based on minor propositions 1 to 4 above, major propositions can be arranged as follows: If the process and coordination with related fields is done well, the inhibiting factors are minimized, the supporting factors are maximized in Population Administration Services through the SIAP Application Program, then Population Administration Services in Batu City to be orderly.

\section{CLOSING}

\section{A. Conclusion}

1. The Population Administration Service Process through the Ready in Batu City Application Program simplifies all administrative processes that have seemed complicated and long. Regarding online services carried out in Batu City through several web sites that are separated based on their needs.

2. The problems faced by the Batu City Government in carrying out Population Administration Services through the SIAP Application Program have been reviewed from various things, namely conditional, participatory, equality of rights, balance of rights and obligations, the government in charge of serving, the community served by the government, the policies that are presented as a basis public services, sophisticated equipment or service facilities, resorts available to formulate in the form of service activities, quality of service that formulates the community in accordance with the standards and principles of community service, management and leadership and community service organizations. The behavior of officials who are involved in community service is viewed from Passionate (passion). Proactive (proactive). Progressive (progressive). Positive (positive). How to see yourself. How to view other people. How to look at work. Tangibles (touchable), physical facilities, equipment, personnel and communication, Reliability (reliable), the ability of the service unit to create the promised service appropriately, Responsiveness (responsibility), willingness to help consumers, responsible for the quality of service provided, Competence (competent), demands to have good knowledge and skills by officials in service members, Courtesy (polite), friendly attitude / behavior, friendly, responsive to consumer desires, willing to make personal contact / relationships, credibility (honest), honest attitude in every effort to attract public trust, Security (safe), Access (convenience), Communications (communication), Understanding the Customer (understand the customer).

3. Coordination with Related Fields Regarding Population Administration through the Ready Application Program in Batu City, channeled to officials who will carry out the program by means of the leadership of public service providers or appointed officials responsible for providing services and resolving complaints / problems in the implementation of public services. public service providers or appointed officials are responsible for the delivery of services and the resolution of complaints / problems in the implementation of public services.

4. Factors that hamper the Batu City Government in Performing Population Administration Services through the Ready Application Program in Batu City, namely the readiness of human resources in carrying out population administration services through the SIAP application program, gaps in the quality of these services occur in addition to due to inadequate facilities and infrastructure factors limited human resources and management of public service systems that are not yet integrated.

5. Factors that support the Batu City Government in Performing Population Administration Services through 
the Ready Application Program, namely the attitude and commitment of the implementers in carrying out population administration services that they are fully committed to using this SIAP application wisely so that it can lead to many good benefits for the citizens of the city. Stone. The understanding of the implementer in carrying out population administration services through the SIAP application program is very familiar with how to operate this application because the application is very easy to understand, so it doesn't take a long time to understand it.

\section{A. Suggestions}

Suggestions for this research are:

a. Practical Suggestions, it is hoped that the results of this research can be used as contributions, input / donations, donations for Batu City Government Apparatus in providing services to the community.

b. 2. Theoretical suggestions, it is hoped that the results of this study can add references for the development of science in the social field among academics. And also as a reference for future researchers who are more in-depth regarding the Population Administration Service Process through the SIAP Application Program in Batu City.

\section{BIBLIOGRAPHY}

Agustino, Leo, 2006. Dasar-Dasar Kebijakan Publik. Bandung : CV. Alfabeta. Arfani, Riza Noer. 2001. "Integrasi Nasional dan Hak Asasi Manusia" dalam

Jurnal Ilmu Sosial dan Ilmu Politik. Volume 5, Nomor 2, November 2001. Yogyakarta: Universitas Gadjah Mada.

Alwasilah, Chaedar. 2002. Pokoknya Kualitatif, Pustaka Jaya, Bandung.

Antwi, K B., Analoui, F., Cusworth, JW. (2007). Pengembangan Sumberdaya Manusia dalam Menghadapi Tantangan Desentralisasi Lokal Pemerintah di Afrika : Bukti empiris dari Ghana.

Bungin, Burhan. 2003. Analisis Data Penelitian Kualitatif Pemahaman Filosofis dan Metodologis Kearah Penguasaan Model Aplikasi.Jakarta : PT.Raja Grafindo Persada.

Cook, Sarah and Macaulay, Steve, 1997, Perfect Empowerment (Pemberdayaan yang Tepat), edisi terjemahan, alih bahasa: Paloepi Tyas R., PT. Elex Media Komputindo, Jakarta.

Darwin. 1983. Pajak Daerah dan Retribusi Daerah. Jakarta:Mitra Wacana Media. Denhardt, Janet V.and Denhardt Robert B. 2000. The New Public Service. 2004. The New Public Service.

2003. The New Public Service : Serving Not Steering. Armonk, N.Y: M.E.Sharpe.

Denhardt, Kathryn G. 2006. The ethics of Public Service. Westport, Connecticut: Greenwood Press.

Dwiyanto. 2006. Melakukan penelitian di tiga provinsi (DI Yogyakarta, sumatera) barat dan Sulawesi Selatan). Reformasi birokrasi publik di Indonesia.

Edwards, George C., III dan Sharkansky, Ira. (1978). The Policy Predicament, San Francisco: W.H. Freeman.

Elvira, Masengi. 2008. Reformasi Birokrasi Pemerintahan: LP3ES, Jakarta. Frederickson, H. George. 1988. Administrasi Negara Baru. Penerjemah: Al-Ghozei Usman. Jakarta: LP3ES.

Frederickson, H. George \& Kevin B. Smith. 2003. The Public Administration Theory Primer. USA: Westview Press.

Gibson, C. H. 1982. "How Industry Perceived Financial Ratios,” Management Accounting (April) : 13 - 19.

Glueck dan Jauch. 1989. Manajemen Strategis dan Kebijakan Perusahaan. Edisi Ketiga. Terjemahan Murad dan Henry. Erlangga. Jakarta.

Grindle, Merilee S. 1997. Getting Good Government. Harvard University Press. Harvard.

Hasibuan, Malayu SP, 2000. Manajemen Sumber Daya Manusia, STIE YKPN, Yogyakarta.

Hasibuan, Malayu S.P. 2008. Manajemen Sumber Daya Manusia. Jakarta: PT. Bumi Aksara.

Hersey, Paul dan Kenneth Blanchard. 1995. Manajemen Perilaku Organisasi; Pendayagunaan SDM. Jakarta. Erlangga.

Helga, Mayona. 2009. Model ideal pelayanan umum kepada masyarakat” dengan studi kasus di Kota Bukittinggi Sumatera Barat.

Hill, Michael. (ed.).1993. The Policy Process: A Reader. New York: Harvester- Wheatsheaf

Howlett, Michael, Ramesh, M, 1995, Studying Public Policy: Policy Cycles and Policy Subsystem, Oxford University Press, Canada.

I Made Leo Agus Jaya. 2003. Peningkatan Kinerja Birokrasi dalam Pelayanan Publik. Penelitian tersebut dilakukan di Sekretariat Daerah Kabupaten Jembrana dengan pendekatan kualitatif.

Irawan, Prasetya, 1993. "Manajemen Sumber Daya Manusia “, STIA-LAN,Jakarta Islamy, M. Irfan. 2002. Prinsip-Prinsip Perumusan Kebijakan Negara. Bumi aksara: Jakarta.

-,1998, Agenda Kebijakan Reformasi Administrasi Negara, Pidato Pengukuhan Guru Besar Ilmu Kebijakan Publik pada Fakultas Ilmu Administrasi Universitas Brawijaya, Malang 
Kartasasmita, Ginanjar. 1997. Administrasi pembangunan : perkembangan, pemikiran, dan praktiknya di Indonesia. LP3ES. Jakarta.

Keban, Yeremias T. 2004. Pengantar Aministrasi Publik. Program MAP UGM, Yogyakarta.

Kotler, Philip. 1995, Manajemen Pemasaran Analisa, Perencanaan, Implementasi, dan Kegunaan, Edisi Kedelapan, Salemba Empat, Jakarta.

Latifah, Melly. 2001. Peranan Keluarga Dalam Pendidikan Karakter Anak.

Lane, V. and Jacobson, R. (1995) "Stock Market reactions to brand extention announcements: The effects of brand attitude and familiarity," Journal of Marketing, Vol. 59 No.1, pp. 63-77.

Lester, James P, and Joseph Stewart, Jr. 2000. Public Policy : An Evolutionary Approach. Belmont, CA : Wadsworth.

Levine, P., B. Rose, S. Green, G. Ransom, and W. Hill. 1990 Pathogentesting of ready-to-eat meat and poultry products collected at federally inspected establishments in the United States, J. Food Prot. 64:1188-1193.

Leonard, Nadler. 1982, Designing Training Programs : The Critical Events Models, USA, Wesley Publishing Company.

Lincol, Y.S. \& Guba, E.G. 1985. Naturalistic Inquiry, $1^{\text {st }}$ edition, Sage Publication, Beverly Hills.

Madina, Kenzhegaranova. 2008. Pengembangan Sumberdaya manusia di Negara berkembang: Republik Kazakhstan

Martoyo, Susilo. 1996, Manajemen Sumber Daya Manusia. Yogyakarta : PT. BPFE Mazmanian, Daniel H., dan Paul A. Sabatier, 1983, Implementation and Public Policy, New York: HarperCollins.

Miles, Mathew B., Michael Hubernman and Johnny Saldana. 2013. Qualitative Data Analysis, A Methods Sourcebook. Edition 3.

Moleong, Lexy J. 2002. Metodologi Penelitian Kualitatif. Bandung: PT. remaja Rosdakarya.

Nakok, Aruan (2003) melakukan penelitian di Provinsi Jawa Timur Surabaya, penelitian ini juga di lakukan di empat Kabupaten Jember, Malang, Tuban dan Pamekasan.

Nawawi, Hadari. 1994. Penelitian Terapan. Cet. 1. Gajah Mada University Press, Yogyakarta.

Notoatmodjo, Soekidjo. 1997. Pendidikan Dan Perilaku Kesehatan. Rineka.

Cipta. Jakarta.

Jakarta.

2003. Pendidikan Dan Perilaku Kesehatan. Rineka. Cipta.

Nugroho, D, Riant. 2003. Kebijakan Publik Formulasi, Implementasi dan Formulasi. Jakarta: PT Elex Media Komputindo.

Osborne, David and Gaebler, 1995. Reinventing Government: How the Enterpreneurial Spirit is Transforming the Public Sector,. Terjemahan Abdul Rosyid. Mewirausakan Birokrasi. PT. Pustaka Binaman Pressindo, Jakarta.

Osborne, David \& Peter Plastrik, 1997. Banishing Bureucracy The Five Strategies for Reinventing Government, Edisi terjemahan, 2001, PPM, Jakarta.

Pan Suk Kim. 2000. Reformasi administrasi di Korea khususnya Korea Selatan dengan studi kasus pada pemerintahan Kim Dae Jung.

Parasuraman, A, Valerie A. Zeithaml, Leonard L. Berry. 1998 SERVQUAL : A Multiple Item Scale For Measuring Consumer Perception Of Service Quality. Journal Of Retailing Vol. 64 No. 1, pp 12-37.

Peraturan Pemerintah Republik Indonesia Nomor 101 tahun 2000 Tentang Pendidikan Dan Pelatihan Jabatan Pegawai Negeri Sipil.

Peraturan Pemerintah Republik Indonesia Nomor 53 Tahun 2010 tentang Disiplin Pegawai Negeri Sipil PP No.30/1980 tentang Peraturan Disiplin Pegawai Negeri Sipil,

Prabu Mangkunegara, 2000. Manajemen Sumber Daya Manusia Perusahaan.

Bandung : PT Remaja Rosdakarya.

Rasyid, M Ryaass. 1997. Makna Pemerintahan, Tinjauan dari Segi Etika, dan Kepemimpinan, Jakarta : Yasif, Watampone.

Ritva Laakso-Manninen, Riitta Viitala. 2007. Competence Management And Human Resource Development, HAAGA-HELIA Publication Series.

Ruliaty. 2007. Melakukan penelitian yang dilaksanakan di Kabupaten Bulukumba, yang merupakan salah satu kabupaten dalam wilayah Provinsi Sulawesi Selatan, dan terletak $153 \mathrm{~km}$ dari Kota Makassar.

Savas, ES. 1987. Privatization: The Key To Better Government, Chatham House Publishers Inc., New Jersey.

Sedarmayanti. 2003. Restrukturisasi dan Pemberdayaan Organisasi Untuk Menghadapi Dinamika Perubahan Lingkungan. Bandung : Mandar Maju.

Siagian, Sondang P. 1997. Filsafat Administrasi. Jakarta : PT Toko Gunung Agung Sikula, Andrew F. (1981), Personel Administration And Human Resources Management, New York.

SM, Anowar, Uddin. 2010. Dampak Good Governance Pembangunan di Bangladesh.

Stephen, Gibb. 2006 adalah pimpinan di Edinburgh Business School. Dia meraih gelar PhD di Strathclyde 
Business School. Dia adalah penulis buku populer di Inggris

Sumartono. 2007. Reformasi Administrasi Dalam Pelayanan Publik (Pidato pengukuhan Guru Besar), Fakultas Ilmu Administrasi - UNIBRAW, Malang

Subarsono. AG. 2006. Analisis Kebijakan Publik, Yogyakarta, Pustaka Pelajar. Stewart, John, 1998. Understanding The Management of Local Government, London, Longman.

Tanvir, Kayani. 2008. Tantangan Sumberdaya Manusia Pembangunan untuk berpacu dengan globalisasi.

Tegene, Abebe, Desta. 2008. Managemen sumberdaya manusia di Negara Ethiopia.

Thoha. 2008. Manajemen pegawai negeri sipil yang dilakukan di lima wilayah propinsi, lima daerah kota dan empat daerah kabupaten

Thoha (1978) dibentuk dari interaksi kerakteristik individu dengan karaktersitik organisasi.

Tjokroamidjojo Bintoro. 2000. Good Government (Paradigma Baru Manjemen Pembangunan), Jakarta : Universitas Indonesia Jakarta.

Triono. 2008. Pengaruh Budaya Organisasi, Kepemimpinan, dan Kompetensi Sumberdaya Manusia terhadap Kinerja Organisasi.

Van Meter, Donald, dan Carl Van Horn, 1975, "The Policy Implementation Process: A Conceptual Framework dalam Administration and Society 6, 1975, London: Sage

Vigoda, Eran (editor). 2002. The Legacy of Public Administration: Bankground and Review. Dalam Public Administration: An Interdisciplinary Critical Analysis. Marcel Dekker, Inc. New York.

Wahab, Solichin, Abdul. 1997. Evaluasi kebijakan Publik. Penerbit FIA UNIBRAW dan IKIP Malang -1999. Ekonomi Politik Pembangunan; Bisnis Indonesia Era Orde Baru dan Di tengah Krisis Moneter, PT Danar Wijaya Brawijaya University Press

Widya. 1986. Manajemen Sumber Daya Manusia. Penerbit Sanyata Sumanasa Wira Sespim Polri, Bandung Winarno, Budi. 2002. Teori dan Proses Kebijakan Publik. Yogyakarta: Media Pressindo.

Zauhar, Soesilo. 1996. Birokrasi, Birokratisasi dan Post Bureaucracy.Malang: Unibraw

http://www.stiami.ac.id, diakses hari Senin, 11 Mei 2015 pukul09.15 WIB. http://www.slideshare.net, diakses hari Senin, 11 Mei 2015 pukul 15.30 WIB.

http://blogspot.com, diakses hari Selasa, 12 Mei 2015 pukul 18.00WIB.

http://www.antarajatim.com, diakses hari Sabtu, 29 November 2014. Pukul 13.43 WIB.

http://www.bmkg.go.id, diakses hari Sabtu, 16 Mei 2015, pukul 11.12 WIB.

http://totoksuharto.blogspot.co.id/2010/05/.html, diakses hari senin, tanggal 5

Oktober 2015, pukul 23.06 WIB.

http://www.rider-system.net, diakses hari Sabtu 16 Mei 2015 Pukul 12.21 WIB.

http://www.untag-smd.ac.id,diakses hari Sabtu 16 Mei 2015 Pukul 12.30 WIB.

http://eprints.undip.ac.id, diakses hari Sabtu 16 Mei 2015 Pukul 12.21 WIB.

$\mathrm{http}: / /$ sipatensidoarjo.com/pelayanan, diakses hari senin, tanggal 5 Oktober 2015, pukul 20.15 WIB.

http://trimiyati.web.ugm.ac.id/wordpress/wp-content/libtik-v.pdf diakses hari Selasa, 20 Oktober 2015, pukul 09.02 WIB.

http://www.kompasiana.com/171717/diklat-calon-widyasiwara-pola-baru-tantangandiakses hari Selasa, 20 )ktobe 2015 pukul 09.20 WIB. 